\title{
ANALISIS PENGARUH PENGUMUMAN STOCK BUYBACK TERHADAP HARGA SAHAM DAN RETURN SAHAM PADA PERUSAHAAN YANG TERDAFTAR DI BURSA EFEK INDONESIA TAHUN 2011-2016
}

\author{
Ainal Husna Hasibuan ${ }^{1)}$, \& Syahrizal Chalil ${ }^{2}$ ** $^{*}$ \\ 1) Fakultas Ekonomi, Universitas Negeri Medan \\ 2) Fakultas Ekonomi, Universitas Negeri Medan \\ E-mail : cokichrp@yahoo.com
}

\begin{abstract}
Abstrak
Penelitian ini berupa penelitian deskriptif kuantitatif dengan pendekatan event study. Populasi dari penelitian ini adalah seluruh perusahaan yang terdaftar di Bursa Efek Indonesia yang melakukan stock buyback tahun 2011-2016. Sampel yang digunakan sebanyak 66 perusahaan yang terdaftar di BEI yang diambil dengan menggunakan metode purposive sampling. Hasil penelitian menunjukkan harga saham dan return saham sebelum pengumuman stock buyback lebih rendah dari sesudah pengumuman stock buyback. Hal tersebut menunjukkan bahwa informasi pengumuman stock buyback direspon secara positif oleh investor. Dengan demikian, dapat disimpulkan bahwa pengumuman stock buyback berpengaruh terhadap harga saham dan return saham perusahaan yang terdaftar di Bursa Efek Indonesia 2011-2016.
\end{abstract}

Kata Kunci : Stock Buyback, Harga Saham, Return Saham

\section{Abstract}

This research is descriptive quantitative research with the event study approach. The population of this study are all companies listed in Indonesia Stock Exchange that the stock-buyback year 2011-2016. The samples used were 66 companies listed on the Stock Exchange are taken by using purposive sampling method. The results showed stock prices and stock returns before the announcement of a stock buyback is lower than after the announcement of a stock buyback. It shows that the stock buyback announcement information responded positively by investors. Thus, it can be concluded that the announcement of a stock buyback effect on stock prices and stock returns of companies listed on the Indonesia Stock Exchange 2011-2016.

Keyword : Stock Buyback, Stock Price, Stock Return

\section{PENDAHULUAN}

Pada tahun 2008, kondisi bursa dan pasar keuangan global sedang mengalami tekanan yang sangat parah. Keterpurukan yang dialami Indonesia ditandai dengan penurunan indeks di bursa saham yang telah mencapai angka lebih dari $11 \%$ pada pertengahan 2008 dan mencapai penurunan $50 \%$ pada penutupan 2008 , sehingga memaksa otoritas bursa harus menghentikan hari perdagangan selama 3 hari untuk mencegah keadaan bursa yang lebih terpuruk lagi yaitu berupa pelarangan short selling dan penetapan auto rejection sampai dengan $10 \%$ (batas atas dan batas bawah). Selain itu, pihak emiten sendiri juga melakukan upaya untuk menyelamatkan kinerja sahamnya melalui adanya pencanangan program stock buyback oleh Pemerintah dan 
BUMN yang diikuti dengan pengendoran aturan stock buyback di bursa saham, yang bertujuan untuk menstabilkan pasar saham. Dengan cara itu, banyak perusahaan yang berusaha untuk memperbaiki kinerja saham dan kinerja keuangannya dengan melakukan stockbuyback, yaitu terdapat 13 perusahaan.

Pada tahun 2013 kembali terjadi penurunan IHSG secara signifikan yang mengakibatkan Otoritas Jasa Keuangan (OJK) mengeluarkan kebijakan bahwa perusahaan dapat melakukan stockbuyback tanpa melalui Rapat Umum Pemegang Saham (RUPS) sehingga pada saat itu terdapat 23 perusahaan yang melakukan stock buyback. Namun pada september 2014, IHSG mengalami kenaikan yang cukup tajam yaitu 5.262,19 bila dibandingkan pada akhir 2013 yang hanya menyentuh 4274,18. Pada 2014 ini, hanya 8 perusahaan yang melakukan stock buyback. Selain pada tahun 2008 dan 2013, di tahun 2015 juga terjadi keterpurukan IHSG yang telah turun selama 3 hari berturut-turut dengan penurunan lebih dari 15 persen yangmengakibatkan terdapat 16 perusahaan yang melakukan stock buyback. Kemudian pada pertengahan 2016, IHSG meningkat 0,89 persen ke level 4.839,66, dan pada saat itu terdapat 9 perusahaan yang melakukan stock buyback.

Dapat dilihat bahwa lebih banyak perusahaan yang akan melakukan stock buyback ketika IHSG melemah dibandingkan saat IHSG menguat. Hal ini mengindikasikan bahwa pada umumnya perusahaan melakukan stock buyback untuk memperbaiki harga sahamnya. Biasanya reaksi harga saham perusahaan akan timbul sejak dilakukannya pengumuman stock buyback. Perkembangan harga saham yang terjadi sesudah pengumuman stock buyback yang dilakukan perusahaan yang terdaftar di Bursa Efek Indonesia tahun 20112016 cenderung stagnant dan seluruh perusahaan yang melakukan buyback dalam periode 2011-2016 mengalami fluktuasi perkembangan return saham yang cukup tajam. Fenomena yang terjadi pada harga saham dan return saham sesudah pegumuman tidak sesuai dengan teori yang ada.

\section{KAJIAN PUSTAKA}

Stock Buyback (Stock Repurchase) Darmadji dan Fakhrudin (2012:148) mengatakan bahwa "Pembelian kembali saham adalah tindakan emiten membeli kembali sebagian saham yang telah beredar atau berada di tangan pemegang saham publik". Menurut Bapepam-LK buyback merupakan tindakan yang dilakukan oleh emiten maupun perusahaan publik untuk membeli kembali saham yang telah ditawarkan kepada masyarakat, baik melalui bursa maupun di luar bursa. Sedangkan menurut Brigham dan Huston (2011:237) mengartikan buyback sebagai suatu transaksi perusahaan untuk membeli kembali sahamnya sendiri yang telah beredar, sehingga jumlah saham yang beredar menurun, harga saham serta Earning Per Share (EPS) menjadi meningkat. Maka dari itu dapat disimpulkan bahwa stock buyback adalah kegiatan membeli kembali saham yang berada di tangan pemegang saham oleh perusahaan. 
JURNAL PLANS

Penelitian Ilmu Manajemen \& Bisnis

ISSN: $1978-7057$

E-ISSN: 2527-306X

\section{Event Study}

Ketika emiten melakukan pembelian kembali saham pada penjelasan sebelumnya, maka investor dan pelaku pasar lainnya harus bisa mempelajari dan memperkirakan reaksi apa yang akan timbul akibat aksi tersebut melalui event study. Peristiwa yang dimaksud dalam penelitian ini adalah peristiwa pengumuman pembelian kembali saham (stock buyback) yang dilakukan perusahaan yang terdaftar di BEI. Dalam event study dikenal istilah event window (jendela peristiwa) / event date (tanggal peristiwa) dan estimation period (periode estimasi). Periode peristiwa disebut juga dengan periode pengamatan / jendela peristiwa (event window) mempunyai panjang yang bervariasi, lama dari jendela yang umumnya digunakan berkisar 3 hari - 121 hari untuk data harian dan 3 bulan - 121 bulan untuk data bulanan. Sedangkan lama periode estimasi yang umum digunakan adalah berkisar dari 100 hari - 300 hari untuk data harian dan berkisar $24-60$ bulan untuk data bulanan.

\section{Signalling Theory}

Junizar dan Septiyani (2013) mengemukakan signalling theory adalah teori yang membahas tentang naik turunnya harga di pasar, sehingga akan memberi pengaruh pada keputusan investor. Sinyal perusahaan dapat dilihat dari reaksi harga saham. Reaksi harga saham dapat diukur dengan menggunakan return saham sebagai nilai perubahan harga atau dengan menggunakan abnormal return. Berdasarkan signaling hypothesis, pembelian kembali saham perusahaan merupakan indikasi bahwa saham dinilai terlalu rendah atau undervalued.

Harga Saham

Harga pasar saham terbentuk melalui mekanisme permintaan dan penawaran di pasar modal. Dari pengertian harga saham menurut para ahli dapat disimpulkan bahwa harga saham adalah harga yang terbentuk sesuai permintaan dan penawaran di pasar jual beli saham dan biasanya merupakan harga penutupan.

Harga saham merupakan cerminan dari nilai suatu perusahaan bagi para investor. Semakin baik perusahaan mengelola usahanya dalam memperoleh keuntungan, semakin tinggi juga nilai perusahaan tersebut di mata para investor. Meskipun demikian saham yang memiliki kinerja baik sekalipun, harganya bisa saja turun karena keadaan pasar.

\section{Return Saham}

Telah diketahui bahwa stock buyback dapat mempengaruhi harga saham. Dengan mempengaruhi harga saham, maka secara langsung stock buyback juga akan mempengaruhi tingkat return saham yang akan diperoleh investor. Menurut Brigham dan Houston (2011:215), return atau tingkat pengembalian adalah selisih antara jumlah yang diterima dan jumlah yang diinvestasikan, dibagi dengan jumlah yang diinvestasikan.Dari beberapa definisi di atas dapat disimpulkan bahwa return saham merupakan tingkat pengembalian berupa imbalan yang diperoleh dari suatu investasi.

\section{METODE PENELITIAN}

Penelitian ini dilakukan di Bursa Efek Indonesia dengan mengakses situs resmi www.idx.co.id 
- Adapun objek penelitian dalam penelitian ini adalah seluruh perusahaan yang memberikan informasi pengumuman buyback periode 2011 hingga 2016, dengan menggunakan data-data yang disediakan oleh Bursa Efek Indonesia. Dengan waktu penelitian selama 2 bulan. Penelitian ini mengambil populasi perusahaan-perusahaan yang terdaftar di Bursa Efek Indonesia pada periode 2011-2016 yang telah melakukan aksi stock buyback. Dari keseluruhan populasi yang akan diteliti, ditentukan sampel dengan menggunakan metode purposive sampling, yaitu cara pengambilan sampel dengan memilih sub-grup dari populasi dengan pertimbangan atau berdasarkan kriteria tertentu, sehingga diperoleh sampel yang mempunyai sifat-sifat sesuai dengan sifat-sifat populasi dan sesuai dengan kriteria. Data yang digunakan dalam penelitian ini merupakan data sekunder yaitu data yang tidak langsung diperoleh dari sumber pertama dan telah tersusun dalam bentuk dokumen tertulis . Data yang diperoleh dalam hal ini adalah data tanggal pengumuman stock buyback, data harga saham dan perusahaan yang melakukan stock buyback yang terdaftar di Bursa Efek Indonesia periode 2011-2016 yang diambil dengan cara mengakses situs resminya yaitu www.idx.co.id dan sumber data lainnya yaitu www.duniainvestasi.com.

Uji normalitas data dalam variabel yang digunakan bertujuan untuk mengetahui bahwa distribusi penyampelan data telah terdistribusi dengan normal. Dalam penelitian ini, untuk melihat normalitas dengan menggunakan uji statistik, uji statistik sederhana dapat dilakukan berdasarkan nilai Kolmogrov Sminorv (K-S). Uji K-S dengan level signifikan 0,05. Dapat dikatakan terdistribusi normal jika nilai $p$ value $>0,05$ dan dikatakan tidak terdistribusi normal jika nilai $p$ value $<\quad 0,05$ (Ghozali,2011). $\mathrm{Uji}$ hipotesis yang digunakan dalam penelitian ini adalah uji paired sampel t-test.Uji ini adalah statistik parametris yang digunakan untuk menguji hipotesis beda dua rata-rata sampel untuk data yang berbentuk interval atau rasio (Sugiyono, 2007:122). Dalam penelitian ini peneliti melakukan uji paired sample t-test dengan menggunakan SPSS versi 22.

\section{HASIL DAN PEMBAHASAN Analisis Statistik Deskriptif}

Tabel 1.

Analisis Statistik Deskriptif Descriptive Statistics

\begin{tabular}{|l|r|r|r|l|}
\hline \multicolumn{5}{|c|}{ Descriptive Statistics } \\
\hline $\begin{array}{l}\text { Harga } \\
\text { Sebelum }\end{array}$ & 66 & 58,00 & 17050,00 & 2251,9848 \\
$\begin{array}{l}\text { Harga } \\
\text { Sesudah }\end{array}$ & 66 & 61,00 & 17350,00 & 2320,2121 \\
$\begin{array}{l}\text { Return } \\
\text { Sebelum } \\
\text { Return }\end{array}$ & 66 &,- 070037 &, 055079 &, 00033973 \\
$\begin{array}{l}\text { Sesudah } \\
\text { Valid N } \\
\text { (listwise) }\end{array}$ & 66 &,- 059322 &, 088710 &, 00172198 \\
\hline
\end{tabular}

$\begin{array}{rrr} & \text { Nilai } & \text { untuk kriteria tinggi } \\ \text { harga } & \text { saham } & \text { sebelum }\end{array}$ pengumumandiperoleh dari 2251,98 + $(1 \times 3445,29)=5697,27$, untuk nilai rendah diperoleh dari 2251,98 - (1 x $3445,29)=-1193,31$. Sedangkan untuk memperoleh nilai sedang yaitu diantara nilai $-1193,31$ dan 5697,27. Terdapat 4 perusahaan $(6,06 \%)$ yang memiliki harga saham tinggi, 62 perusahaan $(93,94 \%)$ yang memiliki harga saham sedang dan tidak ada perusahaan $(0 \%)$ yang memiliki harga 
saham rendah. Sehingga dapat dikatakan bahwasannya harga saham perusahaan sebelum pengumuman stock buyback pada tahun 2011-2016 cenderung berada di tingkat sedang dengan jumlah 62 perusahaan yaitu pada skor $-1193,31$ s/d 5697,27.Dari 66 data yang diamati, harga saham sebelum pengumuman terendah yang berada pada tingkat sedang (58) yaitu PT Trimega Securities pada tahun 2014 dan harga saham tertinggi (17050) dimiliki oleh PT Bukit Asam Tbk pada tahun 2012.

Nilai untuk kriteria tinggi harga saham sesudah pengumuman diperoleh dari 2320,21 $+(1 \mathrm{x}$ $3482,89)=5803,1$ untuk nilai rendah diperoleh dari 2320,21 - (1 x $3482,89)=-1162,68$. Sedangkan untuk memperoleh nilai sedang yaitu diantara nilai $-1162,68$ dan 5803,1. Terdapat 6 perusahaan $(9,09 \%)$ yang memiliki harga saham tinggi, 60 perusahaan $(90,91 \%)$ yang memiliki harga saham sedang dan tidak ada perusahaan $(0 \%)$ yang memiliki harga saham rendah. Sehingga dapat dikatakan bahwasannya harga saham perusahaan sebelum pengumuman stock buyback pada tahun 2011-2016 cenderung berada di tingkat sedang dengan jumlah 60 perusahaan yaitu pada skor $-1162,68 \%$ s 5803,1 . Dari 66 data yang diamati, harga saham sebelum pengumuman terendah yang berada pada tingkat sedang (61) yaitu PT Wintermar Offshore Marine Tbk pada tahun 2013 dan harga saham tertinggi (17350) dimiliki oleh PT Bukit Asam Tbk pada tahun 2011.

Nilai untuk kriteria tinggi return saham sebelum pengumuman diperoleh dari $0,000339+(1 \mathrm{x}$ $0,020115)=0,020454$ untuk nilai rendah diperoleh dari 0,000339 - (1 x
$0,020115)=-0,019776$. Sedangkan untuk memperoleh nilai sedang yaitu diantara nilai $-0,019776$ dan 0,020454 . Terdapat 9 perusahaan $(13,64 \%)$ yang memiliki return saham tinggi, 48 perusahaan $(72,72 \%)$ yang memiliki return saham sedang dan 9 perusahaan $(13,64 \%)$ yang memiliki return saham rendah. Sehingga dapat dikatakan bahwasannya return saham perusahaan sebelum pengumuman stock buyback pada tahun 2011-2016 cenderung berada di tingkat sedang dengan jumlah 48 perusahaan yaitu pada skor $-0,019776 \mathrm{~s} / \mathrm{d} \quad 0,020454$. Dari 66 data yang diamati, return saham sebelumpengumuman terendah (-0,070037)yaitu PT Medco Energi Tbk. pada tahun 2015 dan return saham tertinggi $(0,055079)$ dimiliki oleh PT Intiland Development Tbk pada tahun 2013.

Nilai untuk kriteria tinggi return saham sesudah pengumuman diperoleh dari $0,001721+(1 \quad \mathrm{x}$ $0,028735)=0,030456$ untuk nilai rendah diperoleh dari 0,001721 - (1 $\mathrm{x} 0,028735)=-0,027014$. Sedangkan untuk memperoleh nilai sedang yaitu diantara nilai $-0,027014$ dan 0,030456 . Terdapat 9 perusahaan $(13,64 \%)$ yang memiliki return saham tinggi, 49 perusahaan $(74,24 \%)$ yang memiliki return saham sedang dan 8 perusahaan $(12,12 \%)$ yang memiliki return saham rendah. Sehingga dapat dikatakan bahwasannya return saham perusahaan sesudah pengumuman stock buyback pada tahun 2011-2016 cenderung berada di tingkat sedang dengan jumlah 49 perusahaan yaitu pada skor $-0,027014 \mathrm{~s} / \mathrm{d} \quad 0,030456$. Dari 66 data yang diamati, return saham sesudah pengumuman terendah 
$(-0,059322)$ yaitu PT Media Nusantara Citra Tbk pada tahun 2013 dan return saham tertinggi $(0,088710)$ dimiliki oleh PT Elektronik City Indonesia Tbk pada tahun 2013.

Uji Normalitas

Tabel 2.

Rangkuman Uji Normalitas

\begin{tabular}{|l|c|c|}
\hline \multicolumn{1}{|c|}{ Variabel } & Sig & Ket \\
\hline Harga Saham Sebelum & 0,200 & Normal \\
\hline Harga Saham Sesudah & 0,200 & Normal \\
\hline Return Saham Sebelum & 0,097 & Normal \\
\hline Return Saham Sesudah & 0,200 & Normal \\
\hline
\end{tabular}

Sumber: Data diolah SPSS

Dapat dilihat pada tabel diatas, bahwa data penelitian harga saham sebelum dan sesudah pengumuman stock buyback telah memenuhi syarat normalitas karena sign atau angka Asymp. Sig. (2-tailed) adalah 0,200 > 0,05 dan data penelitian return saham sebelum dan sesudah pengumuman stock buyback telah memenuhi syarat normalitas, karena sign atau angka Asymp. Sig. (2-tailed)return sebelum pengumuman adalah 0,097 $>0,05$ dan sign atau angka Asymp. Sig. (2tailed)return sesudah pengumuman adalah $0,200>0,05$.

Uji Hipotesis

Tabel 3. Rangkuman Paired Sample Correlations

\begin{tabular}{|c|c|c|c|}
\hline Variabel & Corr & Sig & Keterangan \\
\cline { 1 - 3 } Harga Saham & 0,995 & 0,000 & Berkorelasi \\
\hline Return Saham & $-0,291$ & 0,018 & Berkorelasi \\
\hline
\end{tabular}

Sumber: Data diolah SPSS

Dari tabel 4.8 diatas dapat dilihat bahwa pada data harga saham terjadi korelasi diantara kedua variabel yaitu dengan nilai probabilitas dibawah 0,05 (Sig 0,00). Jadi terdapat hubungan antara ratarata harga saham sebelum dan ratarata harga saham sesudah pengumuman stock buyback secara keseluruhan pada tahun 2011-2016 dan pada2011-2016 dan pada data return sahamterjadi korelasi diantara kedua variabel dengan nilai probabilitasdibawah 0,05 (Sig 0,018).

Jadi terdapat hubungan antara rata-rata return saham sebelumdan rata-rata return saham sesudahpengumuman stock buyback secara keseluruhan pada tahun 20112016.

Tabel 4. Rangkuman Uji Paired Samples Test

\begin{tabular}{|l|c|c|}
\hline Variabel & $t$ & Sig \\
\hline Harga Saham & 2,231 & 0,029 \\
\hline Return Saham & 0,284 & 0,778 \\
\hline
\end{tabular}

Setelah melakukan uji statistika melalui uji paired sample test diperoleh nilai t-hitung $>\mathrm{t}$-tabel yaitu sebesar 2,231 > 1,99714 dan tingkat signifikansi $<0,05$ yaitu sebesar 0,029 yang berarti hipotesis diterima yang artinya harga saham sebelum pengumuman stock buyback lebih rendah dari harga saham sesudah pengumuman stock buyback.

Hasil penelitian ini mengindikasikan bahwa adanya reaksi positif dari investor terhadap pengumuman stock buyback ini. Hal ini membuktikan bahwa teori yang meyatakan pengumuman stock buyback yang dianggap sebagai signal positif bagi investor sehingga dapat dibuktikan secara nyata.

Berdasarkan hasil penelitian dapat dilihat pada tabel 4.10 diperoleh t-hitung $<$ t-tabel $0,438<1,99714$ dan nilai signifikan (2-tailed) adalah $0,663>0,05$ yang artinya hipotesis ditolak. Walaupun begitu, terdapat perbedaan rata-rata return saham antara sebelum dan sesudah pengumuman stock buyback yang positif yaitu sebesar 0,003736615 atau 
$0,3736615 \%$ yang menunjukkan ratarata nilai return saham sesudah pengumuman lebih tinggi daripada sebelum dipublikasikannya pengumuman stock buyback.

Hasil penelitian ini mengindikasikan bahwa adanya reaksi positif dari investor terhadap pengumuman stock buyback ini. Namun perbedaan atau reaksi yang terjadi tersebut tidak sesignifikan yang terjadi pada harga saham.

\section{SIMPULAN}

Pada hipotesis pertama penelitian ini menyatakan harga saham sebelum pengumuman stock buyback lebih rendah dari harga saham sesudah pengumuman stock buyback. Peningkatan rata-rata harga sahamsesudah pengumuman, menunjukkan bahwa pengumuman stock buyback memberikan sinyal positif bagi investor, sehingga dapat meningkatkan jumlah permintaan dan penawaran saham perusahaan di pasar modal, dan secara otomatis meningkatkan harga saham. Pada hipotesis kedua menyatakan return saham sebelum pengumuman stock buyback lebih rendah dari return saham sesudah pengumuman stock buyback. Namun perbedaan yang terjadi tidak sesignifikan harga saham sehingga $\mathrm{H}_{\mathrm{a}}$ ditolak dan $\mathrm{H}_{0}$ diterima. Walaupun begitu, dengan adanya perbedaan mean yang positif yang berarti adanya reaksi positif dari investor sesudah pengumuman stock buyback.Perbedaan hasil yang terjadi pada harga saham dan return saham disebabkan karena ketika peningkatan harga yang terjadi tidak sebesar peningkatan di hari sebelumnya, maka walaupun harga meningkat tetapi tingkat returnnya akan menurun.

Karena harga saham dan return saham sebelum pengumuman stock buyback lebih rendah dibandingkan harga saham dan return saham sesudah pengumuman stock buyback maka dapat diartikan bahwa perbedaan tersebut terjadi karena terpengaruhi oleh adanya pengumuman stock buyback tersebut.

\section{DAFTAR PUSTAKA}

Brigham, Eugene dan Joel F. Huston. 2011. Dasar-dasar Manajemen Keuangan. Buku 2. Edisi 11. Penerbit Salemba Empat: Jakarta.

Darmadji Tjiptono, Hendy $\mathrm{M}$. Fakhruddin. 2012. Pasar Modal di Indonesia. Penerbit Salemba Empat: Jakarta.

Ghozali, Imam. 2011. Aplikasi Analisis Multivariat dengan Program SPSS. Badan Penerbit Universitas Diponegoro: Semarang.

Junizar, Muhammad Luky dan Aditya Septiani. 2013.Pengaruh Pengumuman Pembelian Kembali Saham (Buyback) Terhadap Respon Pasar: Studi Pada Perusahaan Yang Terdaftar Di Bursa Efek Indonesia (BEI). Universitas Diponegoro. Volume 2, Nomor 3 hal 1-11. ISSN (Online): 2337-3806.

Sugiyono. 2007. Statistika Untuk Penelitian. Penerbit Alfabeta: Bandung.

www.idx.co.id diakses tanggal 13 Desember 2016.

www.duniainvestasi.com diakses tanggal 13 Desember 2016. 